\title{
The Quality of Yellow Fin Tuna Powder (Thunnus Albacores) as a Natural Flavoring Alternative
}

\begin{abstract}
Fadila
1 Diploma Three Nutrition Study Program, Department of Nutrition Poltekkes Ministry of Health Ternate 2 Undergraduate Study Program in Applied Nutrition and Dietetics, Department of Nutrition, Poltekkes, Ministry of Health, East Kalimantan
\end{abstract}

\begin{abstract}
Flavoring is already commonly used by the community, but on the market, flavoring generally contains monosodium glutamate (MSG). Alternative processed yellow fin tuna (Thunnus albacores) into natural flavoring fish powder without MSG becomes interesting and very useful for reducing MSG intake in the people of North Maluku. This type of research is experimental research conducted in September November 2018 in the SIG Laboratory, Bogor for chemical quality testing (sodium, water, protein, and total fat) and Food Organizing Laboratory for Nutrition Department of Health Ministry of Ternate for making fish powder and organoleptic quality tests (color, texture, aroma, and taste). Chemical test results obtained sodium content of $3204.79 \mathrm{mg} / 100 \mathrm{~g}$ of sample, moisture content of $6.08 \%$, protein of $48.76 \%$, and total fat of $3.28 \%$; and the organoleptic test results obtained a mean \pm SD of the color aspect of $4.0 \pm$ 0.7 , texture of $3.5 \pm 0.9$, aroma of $4.1 \pm 0.8$, and taste of $3.7 \pm 1,0$. It was concluded that the heating process (roasted and oven-dried) affected the chemical quality of yellow fin tuna powder, and obtained sodium $3204.79 \mathrm{mg} / 100 \mathrm{~g}$, Water content $6.08 \%$, protein content $48.76 \%$, and total fat $3.28 \%$; and in terms of organoleptics, the average panelist likes color and aroma, while aspects of taste and texture are only part of the panelists who say they like.
\end{abstract}

Keywords: Yellow fin tuna powder, chemical quality, organolptic quality, flavoring, local food.

\section{INTRODUCTION}

Generally, flavorings on the market today contain a lot of Monosodium Glutamate (MSG), which is the sodium salt of glutamic acid, which is a flavor compound and has been widely consumed throughout the world as a flavor enhancer, because the addition of MSG will make food taste better. more delicious(Rangkuti, Suwarso, \& Hasibuan, 2012). Although the use of MSG is allowed, if it is excessive it is also not good for health. Therefore, currently there are non-MSG powdered broth products that are safe for health, but generally made from chicken and beef.

In North Maluku, public consumption is dominated by consumption of seafood. The potential of fish resources (standing stock) reaches 1,035,230 tons per year with a sustainable potential (maximum sustainable yield) of 517,000 tons per year(Bank Indonesia Maluku Utara, 2017). North Maluku waters are the migration route for large pelagic fish, especially tuna. This potential is supported by its geographical location which is directly adjacent to the Pacific Ocean, Seram Sea, Maluku Sea, Halmahera Sea and Banda Sea which are the entry points for Indonesian Traffic(Kementerian Kelautan dan Perikanan, 2011).

One of the most popular tuna species is the yellowfin tuna (yellowfin tuna) which has the Latin name Thunnus Albacares. Tuna has a high protein content, ranging from $22.6-26.2 \mathrm{~g} / 100 \mathrm{~g}$ of meat and low in fat ranging from 0.2 to $2.7 \mathrm{~g} / 100 \mathrm{~g}$ of meat, minerals calcium, phosphorus, iron and sodium, vitamins $\mathrm{A}$ (retinol), and B vitamins (thiamin, riboflavones, and niacin). The edible portion of tuna ranges from 50\% $60 \%$. The protein content in the white meat of tuna is higher than the red meat. In contrast to the fat content, the white meat of tuna fish is lower than the red meat. This fish has a high selling value, and is one of the most sought after and stolen types of fish from Indonesian seas. That's because it tastes delicious. The high content of essential nutrients in tuna is able to nourish adults and educate children(Rahajeng, 2012) 
In Indonesia, the manufacture of flavorings is only made from chicken, beef, while the people of North Maluku tend to prefer fish consumption. Yellowfin tuna is a local food that can be used as a basic ingredient for processed food products. If this type of fish is processed into flavoring without MSG, it is hoped that it can be a safe alternative to flavoring for use by the people of North Maluku. Based on this, researchers are interested in making yellowfin tuna powder as an alternative flavoring agent, which will be analyzed for its chemical and organoleptic qualities.

\section{Materials And Method}

This research is an experimental study, which began with the manufacture of fish powder made from yellowfin tuna, referring to a homemade recipe by Manggarayu (2017), which replaced the basic ingredients with yellowfin tuna. Furthermore, chemical quality tests were carried out to determine the levels of sodium, water, protein and total fat; and organoleptic quality test to determine the level of preference for color, texture, aroma, and taste of yellowfin tuna fish powder. This research was conducted in September November 2018.

The ingredients for making yellow fin tuna powder are $1.9 \mathrm{~kg}$ fresh yellow fin tuna, $600 \mathrm{ml}$ mineral water, $100 \mathrm{gr}$ salt, $1 \mathrm{~kg}$ garlic, $130 \mathrm{gr}$ onion, $750 \mathrm{gr}$ carrot, $150 \mathrm{gr}$ scallion. The tools used are food scales, measuring cups, frying pans, blenders, filters, microwaves, basins, sterile containers, knives, stoves. The method of preparation is that the fish is separated from the head, skin, bones and entrails, washed thoroughly, mix all the ingredients in a blender, smooth in a baking dish and steamed, then roasted without oil until golden brown, then flatten in a baking dish, through the roasting process in the oven and Blended to get yellowfin tuna powder with a fine texture of 870 grams, then put in a tightly closed sterile container.

The chemical quality test for sodium content was carried out by the 18-13-1/MU/SMM-SIG ICP-OES method, the water content test was carried out using the SNI 01-2891-1992 point 5.1 method, the Protein Concentration Test was performed using the Formol Titration Method (18-8-31). /MU/SMM-SIG, Kjeltec), and Total Fat Content Test using Soxhlet method according to SNI 01-2891-1992 (18-8-5/MU/SMM-SIG, Weilbull) (BSN., 1992; BSN., 2006a ; BSN., 2006b). Furthermore, the organoleptic quality test was carried out using the standard method from SNI 01-2346-2006 (BSN., 2006c), with a hedonic scale/favorite level covering 5 scales: (5) Very like, (4) Like, (3) Neutral, (2) Dislike, (1) Dislike very much, using 30 untrained panelists from students of the Ternate Health Polytechnic Department of Nutrition.

The chemical test results data obtained were processed quantitatively descriptively with double replication. Then, the organoleptic test results data obtained were then tabulated on the assessment results, calculated percentages, mean values, and standard deviations (SD).

\section{Result}

The results of the chemical test of yellowfin tuna powder are in Table 1, which shows that the sodium content in yellowfin tuna powder is $3204.79 \mathrm{mg} / 100 \mathrm{~g}$ sample, water content is $6.08 \%$, protein is $48.76 \%$, and total fat by $3.28 \%$.

Table 1. Chemical Quality Test Results on Yellowfin Tuna Fish Powder Sample

\begin{tabular}{|c|c|c|c|}
\hline No & Parameter & Unit & Hasil \\
\hline 1 & Natrium & $\mathrm{mg} / 100 \mathrm{~g}$ & 3204,79 \\
\hline 2 & Kadar Air & $\%$ & 6,08 \\
\hline 3 & Protein & $\%$ & 48,76 \\
\hline 4 & Lemak Total & $\%$ & 3,28 \\
\hline
\end{tabular}

The results of the organoleptic quality test on samples of yellowfin tuna powder are presented in Table 2. In the specification of the color assessment, the highest percentage of preference level was obtained in the like category as much as $73.3 \%$, then another $16.7 \%$ said they liked it, $6.7 \%$ dislike, and the least is neutral as much as $3.3 \%$, with a mean \pm SD of $4.0 \pm 0.7$. Furthermore, in the specification of the assessment of texture, the most expressed liking for $46.7 \%$, then $30.0 \%$ neutral, $16.7 \%$ disliked, and $6.7 \%$ strongly liked, with a mean \pm SD of $3.5 \pm 0.9$. In the specification of the assessment of the aroma, there are $43.3 \%$ saying they like it, $36.7 \%$ really like it, $16.7 \%$ are neutral, and at least $3.3 \%$ don't like it, with a mean \pm SD value of $4.1 \pm 0$ 
,8. Here, in the specifications for the assessment of taste, there are $50.0 \%$ expressed liking, $20.0 \%$ strongly like, $16.7 \%$ dislike, and $13.3 \%$ neutral, with a mean \pm SD value of $3.7 \pm 1.0$.

Table 2. Results of Organoleptic Quality Test on Yellowfin Tuna Fish Powder Sample

\begin{tabular}{|c|c|c|c|c|c|c|c|c|}
\hline \multirow{2}{*}{$\begin{array}{c}\text { Tingkat Kesukaan } \\
\text { (skala hedonik) }\end{array}$} & \multicolumn{9}{|c|}{ Spesifikasi Penilaian } & \multicolumn{2}{c|}{ Rasa } \\
\cline { 2 - 11 } & \multicolumn{2}{|c|}{ Warna } & \multicolumn{2}{c|}{ Tekstur } & \multicolumn{2}{c|}{ Aroma } & n & $\%$ \\
\cline { 2 - 11 } & $\mathrm{n}$ & $\%$ & $\mathrm{n}$ & $\%$ & $\mathrm{n}$ & $\%$ & 6 & 20,0 \\
\hline Sangat suka (5) & 5 & 16,7 & 2 & 6,7 & 11 & 36,7 & 6 & 50,0 \\
\hline Suka (4) & 22 & 73,3 & 14 & 46,7 & 13 & 43,3 & 15 & 5,7 \\
\hline Netral (3) & 1 & 3,3 & 9 & 30,0 & 5 & 16,7 & 4 & 13,3 \\
\hline Tidak Suka (2) & 2 & 6,7 & 5 & 16,7 & 1 & 3,3 & 5 & 16,7 \\
\hline Sangat Tidak Suka (1) & 0 & 0,0 & 0 & 0,0 & 0 & 0,0 & 0 & 0,0 \\
\hline Total & 30 & 100,0 & 30 & 100,0 & 30 & 100,0 & 30 & 100,0 \\
\hline Mean \pm SD & $4,0 \pm 0,7$ & $3,5 \pm 0,9$ & $4,1 \pm 0,8$ & $3,7 \pm 1,0$ \\
\hline
\end{tabular}

\section{Discussion}

The use of heat in the food processing process is very influential on the final product. According to Sundari, Almasyhuri, and Lamid (2015), dry processing (frying and roasting) can reduce the weight of fresh food more than wet processing (steaming and boiling). Riansyah, Supriadi, and Nopianti (2013), reported that differences in oven temperature affect the moisture content, ash content, protein content and carbohydrate content. As happened in the process of making yellowfin tuna powder, that based on the results of chemical tests on the final product of yellowfin tuna powder, it is different from the chemical composition of fresh, unprocessed yellowfin tuna based on (Fachmann \& Hoorfar, 2017).

The results of the chemical quality test of sodium in yellowfin tuna powder were $3204.79 \mathrm{mg} / 100 \mathrm{~g}$ of fish powder sample. This result is different when compared to the sodium content of fresh yellowfin tuna which is only $37 \mathrm{mg} / 100 \mathrm{gr}$ (Rehbein and Oehlenschlager, 2009). The increase in sodium value in processed fish powder products can be caused by the addition of other ingredients (Wulandari and Handarsari, 2010) in the composition of the ingredients for making yellowfin tuna fish powder, including salt (39 mg Na/100 gr), garlic (46 mg Na/100 g), onions (12 mg Na/100 g), carrots (43 mg Na/100 g), and leeks (30 mg Na/100 g) (Kemenkes. RI., 2018). Increased sodium levels can also be caused by processing techniques. According to Ayustaningwarno (2014) Processing using oven drying technique reduces the water content, increasing the sodium content in the material. In general, WHO in Almatsier (2005) recommends limiting the consumption of table salt to 6 grams a day (equivalent to $2400 \mathrm{mg}$ sodium). The sodium content of fish powder is still included in the very safe category for consumption when compared to the same amount of salt (6 grams) which only contains about $192.3 \mathrm{mg}$ of sodium, so it can be used as a natural food additive.

The water content in the yellowfin tuna powder product from the chemical test results was obtained at $6.08 \%$, lower than the water content of fresh yellowfin tuna $(71 \mathrm{gr} / 100 \mathrm{gr})$ (Rehbein and Oehlenschlager, 2009), this can be caused by the drying process through the oven with the aim of reducing the water content of the material so that it can be processed into fish powder, which is also useful as a preservative for the final product. Drying is a method for removing or removing some of the water from a material by evaporating the water using heat energy. Usually the water content of the material is reduced to a limit so that microbes can no longer grow in it. The principle of the drying oven method is that the water contained in a material will evaporate when the material is heated at a temperature of $105 \mathrm{oC}$ for a certain time. The difference between the weight before and after heating is the water content(Astuti \& Nugroho, 2010).

Research by Riansyah et al. (2013) on the effect of differences in temperature and drying time on the characteristics of salted fish in Sepat Siam also shows that drying reduces the amount of water content in the ingredients. It was further explained that the decrease in the value of this moisture content clearly showed that the amount of water loss increased with increasing drying temperature.

The water content in the yellowfin tuna powder, when compared to the quality requirements of SNI 012715-1996 fish meal (BSN., 1996) at a quality value of $1(10 \%)$ is also lower, but in accordance with the quality standard of fish meal according to LIPI. (1999) which states that high quality fish meal has a water 
content of between $6 \%-10 \%$. The water content of the product is related to the solubility. The higher the water content of the product, the more difficult it is to dissolve the product in water, because the product tends to form larger granules. Likewise, solubility is also influenced by the water content of the dissolved material, the lower the water content of the material, the faster the time to dissolve back in the water(Nabil, 2005).

The protein content of yellowfin tuna powder is $48.76 \%$, when compared to the crude protein content (minimum) from SNI 01-2715-1996, which is slightly higher than the quality standard 3, which is $45 \%$. This result is higher than the protein content of fresh yellowfin tuna (23 g/100 g)(Fachmann \& Hoorfar, 2017). In line with several similar studies, namely Yuarni et al. (2015) which showed that there was an increase in protein content with decreasing water content in salted catfish. He added that this was due to the salting out process so that protein solubility was reduced. As a result, the protein separates as a precipitate. According to Adawyah (2007), decreased water content will result in an increase in the protein content in the material. The use of heat in food processing can reduce the percentage of water content which causes the percentage of protein content to increase. This proves that oven drying can be a factor that affects the increase in protein content.

The results of the total fat content of fish powder showed the results of $3.28 \%$ (3.28 g/ $100 \mathrm{~g}$ of material) total fat, while according to Rehbein and Oehlenschlager (2009) the initial fat content of fresh yellowfin tuna before processing was $15 \mathrm{~g}$. When compared with the standard of total fat content according to SNI 012715-1996 quality 1 of $8 \%$, the yield of yellowfin tuna powder is lower in fat content. This result is inversely proportional to the research of Riansyah et al. (2013) that the increase in the value of fat content in fish drying continues with the longer time used during the drying process up to 24 hours. This is because the longer the time and the higher the temperature used in the drying process, the more it causes an increase in fat content and is inversely proportional to the water content value which increasingly shows a decrease with the higher the temperature and time used during the drying process. This difference may be related to the different drying methods used. Nurbayasari, Utomo, Basmal, and Hastarini (2017) concluded that differences in the drying process can affect the fatty acid content of fish, as seen in the results of the study that the conventional drying method resulted in decreased levels of fatty acids while in oven drying the fatty acid content increased. Fish powder research using oven drying method so that it is in line with the research results.

Organoleptic test is a way of testing food products using human senses on the characteristics of food products, including taste, aroma, color, and texture(Bawinto, Mongie, \& NKasanger, 2015). The results of organoleptic testing recommend the feasibility of these food products for consumption. In the organoleptic test of food products, the first appearance that is seen directly by the panelists is color. The quality of the food used is very dependent on the color it has. The color of processed food products will change during the cooking process. Based on the results of organoleptic tests on yellowfin tuna powder, the response of 30 panelists to the color obtained a mean \pm SD value of $4.0 \pm 0.7$, which means that the panelists liked the color of yellowfin tuna powder as a natural flavoring. The color of yellowfin tuna powder gives the impression of liking from the panelists because of the slightly brown color obtained from the fish and the processing process.

One of the parameters used in the flavor organoleptic test which aims to determine the compactness of the resulting flavor is texture(Syah, 2020). Assessment of the texture of a product can be assessed using the sense of touch, namely through touch stimuli. The results of the organoleptic test on the texture of yellowfin fish powder, obtained a response from 30 panelists with a mean \pm SD value of $3.5 \pm 0.9$, which indicates that most of the panelists like the texture. The texture of the yellowfin tuna powder produced is a fine powder, the same as the texture in general synthetic flavoring powder products. The fine texture of yellowfin tuna powder is related to its low water content, which determines the high level of solubility when mixed in food(Nabil, 2005)

The aroma of food can be used as a measure in determining the superiority of a food product that uses the sense of smell(Winarno, 2004). The results of the organoleptic test on the aroma of yellowfin tuna powder, received a good response from the panelists, namely with a mean \pm SD value of $4.1 \pm 0.8$, which means that many respondents chose to like (43.3\%) and really like (43.3\%). 36,7). The aroma of yellowfin tuna fish powder can be used as a natural flavoring because it gives the impression of being liked by panelists because of its delicious aroma which describes the savory aroma of fish that is different from synthetic flavorings. Aroma components are recognized if they are in the form of gases or vapors, which are formed by the 
amount of volatile components or compounds that produce vapors released by a product, which will be affected by temperature and natural components(Kanza, Sudarti, \& Maryani, 2020). The aroma of food greatly affects the reaction to the level of preference, especially if the food contains glutamic acid which can trick the brain as if it has tasted something delicious(Mulyono, 2006).

Taste is one of the important components of food products, which is formed from the sensation that comes from the combination of the constituent ingredients and their composition in a food product that is captured by the sense of taste and is one of the supporters of taste that supports the quality of a product(Pramitasari, 2010). The results of the organoleptic test on the taste of yellowfin tuna fish powder, the panelists responded well enough to the mean \pm SD value of $3.7 \pm 1.0$, which showed that some panelists (50\%) liked and $20 \%$ liked the taste of fish powder very much. yellowfin tuna as a flavoring, because of its strong and savory taste of fish, as expected from a flavoring that can give a savory taste and add a pleasant taste to a food. It's the same with synthetic flavorings that have been circulating in the community. The addition of salt and other seasonings in the manufacture of yellowfin tuna fish powder aims to increase the taste of fish powder as a natural flavoring. Salt is a very important spice in everyday life, and almost all dishes are added with salt. Usually, food will have a taste if it contains at least 0.3 percent salt, less than that the food will taste bland(Winarno, 2004). Garlic, onions, carrots, and scallions are like that, adding a savory sensation to the yellowfin tuna powder. According to Sabri, Supriharti, and Gunawan (2006), natural flavorings are more beneficial for consumption because they provide additional nutrients and do not have a negative impact on health.

\section{Conclusion}

1. Processing by heating (roasting and drying by oven) can affect the chemical quality of the final product. Yellowfin tuna fish powder contains $3204.79 \mathrm{mg} / 100 \mathrm{~g}$ of sodium, $6.08 \%$ water content, $48.76 \%$ protein content, and $3.28 \%$ total fat.

2. In terms of organoleptic, on average, panelists like color and aroma, when compared to taste and texture, only some panelists like taste and texture.

\section{Recomendation}

It is recommended that further research be carried out with variations in substitution of other ingredients to increase the nutritional value and organoleptic quality.

\section{Reference}

1. Adawyah, R. (2007). Pengolahan dan Pengawetan Ikan. Jakarta: Bumi Aksara.

2. Astuti, D., \& Nugroho, F. (2010). Buku Petunjuk Praktikum Laboratorium Air. Surakarta: UMS.

3. Bank Indonesia Maluku Utara. (2017). Kajian Ekonomi dan Keuangan Regional Provinsi Maluku Utara. Maluku Utara: Bank Indonesia Provinsi Maluku Utara.

4. Bawinto, A. S., Mongie, E., \& NKasanger, B. E. (2015). Analisa Kadar Air, pH, Organoleptik dan Kapang Pada Produk Ikan Tuna (Thunnus Sp) Asap, di Kelurahan Girian Bawah Kota Bitung, Sulawesi Utara. Universitas Sam Ratulangi, Manado.

5. Fachmann, M. S., \& Hoorfar, J. (2017). Molecular Methods for Assessment of Fish and Fish Product Integrity. Trends in Fish Processing Technologies, 277-290.

6. Kanza, N. R. F., Sudarti, S., \& Maryani, M. (2020). Pengaruh Paparan Medan Magnet Extremely Low Frequency (ELF) terhadap pH dan Daya Hantar Listrik pada Proses Fermentasi Basah Kopi Liberika (Coffea liberica) dengan Penambahan $\alpha$-Amilase. ORBITA: Jurnal Kajian, Inovasi dan Aplikasi Pendidikan Fisika, 6(2), 315-321.

7. Kementerian Kelautan dan Perikanan. (2011). Kelautan dan Perikanan dalam Angka 2011. Jakarta: Pusat Data Statistik dan Informasi.

8. Mulyono. (2006). Zat Aditif Makanan. Yogyakarta: Media Pressindo.

9. Nabil, M. (2005). Pemanfaatan Limbah Tulang Ikan Tuna (Thunnus sp.) sebagai Sumber Kalsium dengan Metode Hidrolisis Protein. Institut Pertanian Bogor., Bogor.

10. Nurbayasari, R., Utomo, B. S. B., Basmal, J., \& Hastarini, E. (2017). Pemurnian Minyak Ikan Patin dari Hasil Samping Pengasapan Ikan. Jurnal Pascapanen dan Bioteknologi Kelautan dan Perikanan, 11(2), 171-182.

11. Pramitasari, D. (2010). Penambahan Ekstrak Jahe dalam Pembuatan Susu kedelai Bubuk Instan dengan Metode Spray Drying . Komposisi Kimia, Uji Sensoris dan Aktivitas Antioksidan. Universitas Sebelas Maret Surakarta, Surakarta.

12. Rahajeng, M. (2012). Ikan Tuna Indonesia. Jakarta: Kementerian Perdagangan RI. 
13. Rangkuti, R. H., Suwarso, E., \& Hasibuan, P. A. Z. (2012). Efek Pemberian Monosodium Glutamat (MSG) terhadap Terbentuknya Mikronukleus pada Sel Darah Merah Mencit. Journal of Pharmaceutics and Pharmacology, 1(1).

14. Riansyah, A., Supriadi, A., \& Nopianti, R. (2013). Pengaruh Perbedaan Suhu dan Waktu Pengeringan terhadap Karakteristik Ikan Asin Sepat Siam (Trichogaster Pectoralis) dengan Menggunakan Oven. Jurnal Fishtech, 2(1), 53-68.

15. Sabri, E., Supriharti, D., \& Gunawan, E. U. (2006). Efek Pemberian Monosodium Glutamate (MSG) Terhadap Perkembangan Embriomencit (Mus musculus 1.) Strain DDW Selama Periode Pra Implantasi Hingga Organogenesis. Jurnal Biologi Sumatera, 1(1), 8-14.

16. Sundari, D., Almasyhuri, A., \& Lamid, A. (2015). Pengaruh Proses Pemasakan Terhadap Komposisi Zat Gizi Bahan Pangan Sumber Protein. Media Litbangkes, 25(4), 235 - 242.

17. Syah, M. (2020). Pemanfaatan Air Limbah Rebusan Ikan Tamban (Sardinella Sp.) Sebagai Flavor Pasta Alami Dengan Berbagai Suhu Pemanasan. Universitas Maritim Raja Ali Haji, Tanjungpinang.

18. Winarno, F. G. (2004). Keamanan pangan, Jilid 2. Bogor: M-Brio Press 